\title{
Succession of phytoplankton assemblages in relation to estuarine hydrodynamics in the Ría de Vigo: A box model approach*
}

\author{
B.M. MÍGUEZ ${ }^{1}$, L. FARIÑA-BUSTO'1, F.G. FIGUEIRAS² and F.F. PÉREZ ${ }^{2}$ \\ ${ }^{1}$ Universidade de Vigo, Facultad de Ciencias, Campus Lagoas-Marcosende, 36200 Vigo, Spain. \\ E-mail: bmiguez@uvigo.es \\ ${ }^{2}$ Instituto de Investigacións Mariñas, C.S.I.C, Eduardo Cabello 6, 36208 Vigo, Spain.
}

\begin{abstract}
SUMMARY: Two phytoplankton succession events (September-October 1993 and March 1994) in the Ría de Vigo were studied in relation to their hydrodynamic context. By means of a circulation box model we calculated horizontal and vertical residual fluxes as well as budgets of phytoplankton associated with them. This allowed us to assess the importance of the two factors involved in the selection processes: one hydrodynamic (dependent upon physical dispersion) and one biogeochemical (involving all other processes such as growth, mortality and grazing). The first period was characterised by a downwelling event which produced a reversal of the estuarine circulation pattern (horizontal velocity $=4 \mathrm{~km} \mathrm{~d}^{-1}$ and downward velocities up to $9 \mathrm{~m} \mathrm{~d}^{-1}$ ). This provided suitable conditions for the blooming of Gymnodinium catenatum favoured by its capacity to swim, while the diatom community almost disappeared. The second period corresponded to an upwelling $\rightarrow$ relaxation sequence. During upwelling (horizontal velocity $=6 \mathrm{~km} \mathrm{~d}^{-1}$; upward velocities up to $12 \mathrm{~m} \mathrm{~d}^{-1}$ ), Thalassiosira spp. was dominant. It is suggested that the less energetic conditions associated with the relaxation event (horizontal velocity=1 $\mathrm{km} \mathrm{d}^{-1}$; upward velocities $<1 \mathrm{~m} \mathrm{~d}^{-1}$ ) favoured the selection of Chatoceros spp. due to its lower sinking rate.
\end{abstract}

Key words: estuarine circulation, succession, box model, Gymnodinium catenatum, Chaetoceros spp., Thalassiosira spp., Ría de Vigo.

\section{INTRODUCTION}

The hydrodynamic regime has a direct effect on the distribution of populations of phytoplankton since it implies a biomass advection (the so-called 'physical dispersion' in Painchaud et al., 1996). In addition to the hydrodynamic factor, the distribution is also determined by many other processes, which we will hereafter call "biogeochemical". These processes include growth, mortality and grazing, passive sedimentation and swimming, which are highly depen-

\footnotetext{
*Received October 4, 1999. Accepted May 15, 2000.
}

dent on the hydrodynamic conditions. The Ría de Vigo (NW coast of Spain, Fig. 1) constitutes a good example of this connection since its high biological productivity is remarkably affected by estuarine hydrodynamics (Prego, 1993; Nogueira et al., 1997; Tilstone et al., 1999). According to Dyer (1973) and Beer (1983), the Ría de Vigo can be considered as a partially mixed positive estuary, which means that typical residual transport of water along the estuary is two-layered (Prego et al., 1990). There is an inward more saline flow in the bottom layer and a seaward flow in the upper one, with the development of a zero velocity depth between them (see Fig. 2). Northerly 
winds which are especially common during spring and summer lead to the upwelling of ENACW (Eastern North Atlantic Central Water), which enhances the residual circulation in two layers as it lifts cold and nutrient-rich water (Prego and Fraga, 1992) towards the Ría. Southerly winds, on the other hand, generate downwelling, forcing surface low-nutrient waters towards the head of the estuary where they pile and eventually sink, which can bring about the reversal of residual circulation (Rosón et al., 1997). Further descriptions of the hydrodynamic regime are provided in Torres López et al. (2001) and Souto et al. (2001). In general terms, a shift from diatom to dinoflagellate populations associated with the transition from upwelling (turbulence and nutrient abundance) to downwelling conditions (stratification and depletion of nutrients) can be observed (Margalef $e t$ al., 1955; Margalef, 1958; Figueiras and Pazos, 1991; Figueiras and Ríos, 1993).

For all this apparent connection, there is a lack of studies linking estuarine hydrodynamics and phytoplankton dynamics, partly due to the complexity of the system, and in general descriptive viewpoints have been maintained. To overcome this difficulty, box model approaches such as the one we propose here are available. These types of models have been applied to the study of pollutants and nutrient cycles (Prego, 1992; Álvarez-Salgado et al., 1996; Simpson and Rippeth, 1998; Rosón et al., 1999), yet recently they have also proven to be a very useful tool for gaining insight into bacterial (Painchaud et $a l ., 1996)$ and phytoplankton dynamics (Tilstone et al., 2000).

By means of a 2-D box model we will first make a quantitative description of residual circulation in the Ría de Vigo during two periods corresponding to very different contexts. The first period corresponded to a typical autumn-downwelling situation characterised by a bloom of the red-tide dinoflagellate, Gymnodinium catenatum, which developed as the diatom community virtually disappeared. The second period corresponds to the relaxation of the upwelling conditions, with an interesting shift between two genera of diatoms, Thalassiosira spp. and Chaetoceros spp. Furthermore, we will estimate the advection of these groups of phytoplankton and compare it with the net budget of their standing stock. The box model results will allow us first to separate and then to assess both the hydrodynamic and the biogeochemical effect on the evolution of phytoplankton communities. This constitutes the most innovating contribution of this work.

\section{MATERIAL AND METHODS}

The Ría de Vigo was sampled 6 times in approximately 2 weeks corresponding to 2 different periods (September 27 to October 8, 1993 and March 6 to March 24, 1994). During these periods, 4 stations were sampled (Fig. 1) aboard the "Lampadena" vessel at the same tidal cycle. A CTD-fluorescence sampler was used to obtain S-T profiles and also to determine the depths where up to 5 seawater samples were to be collected, using 5-litre Niskin bottles fitted with reversing thermometers. Aliquots were taken from the Niskin bottles and frozen for the analysis of nutrients in the laboratory using a Technicon AAII SFA auto analyser. The method of reduction to nitrites in a $\mathrm{Cd}-\mathrm{Cu}$ column was used to determine nitrate concentration (Mouriño and Fraga, 1985). Phytoplankton samples were preserved in Lugol's iodine, sedimented in $50 \mathrm{ml}$ composite sedimentation chambers and eventually counted to the species level.

The Ekman cross-shore $\left(\mathrm{Q}_{\mathrm{x}}\right)$ and along-shore $\left(\mathrm{Q}_{\mathrm{y}}\right)$ transport component was calculated according to Wooster et al. (1976).

$$
\mathrm{Q}_{\mathrm{x}, \mathrm{y}}=\frac{\rho_{\mathrm{a}} \mathrm{C}_{\mathrm{d}}|\mathrm{V}| \mathrm{V}_{\mathrm{y}, \mathrm{x}}}{\mathrm{f} \rho_{\mathrm{w}}}
$$

where $\rho_{\mathrm{a}}$ is the air density $\left(1.22 \mathrm{~kg} \mathrm{~m}^{-3}\right), \mathrm{C}_{\mathrm{d}}$ is the empirical drag coefficient $\left(1.3510^{-3}\right.$, according to Hidy, 1972), $\mathrm{V}_{\mathrm{y}, \mathrm{x}}$ is the vector corresponding to the estimated wind speed on the sea surface, with magnitude $|\mathrm{V}|, \mathrm{f}\left(9.94610^{-5} \mathrm{~s}^{-1}\right)$ is the Coriolis parameter, and $\rho_{w}$ the density of sea water $\left(\rho_{w} \sim 1025 \mathrm{~kg} \mathrm{~m}^{-3}\right)$.

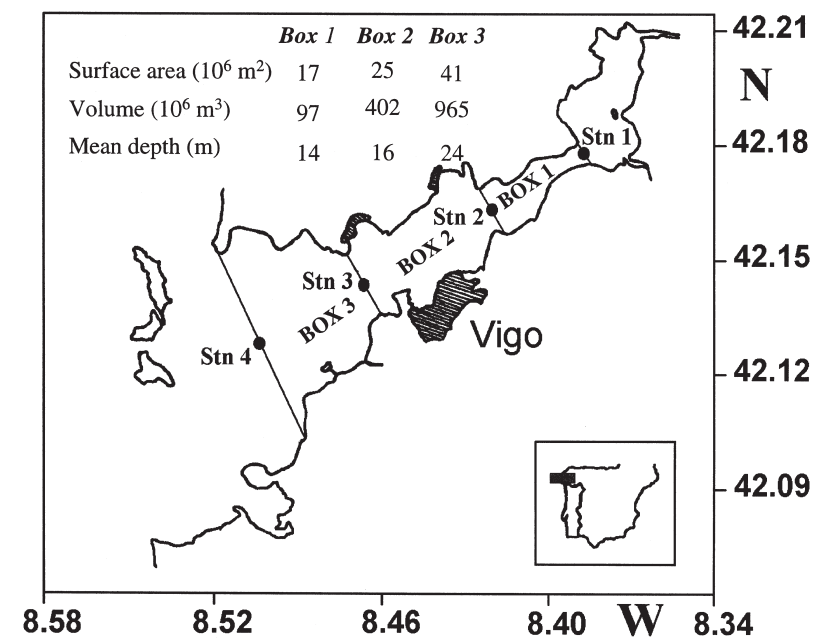

FIG. 1. - Study area (Ría de Vigo, NW of the Iberian Peninsula), sampling stations and boxes. Box dimensions are given in the table. 
The cross-shore transport $\left(\mathrm{Q}_{\mathrm{x}}\right)$ is associated with winds that have a north-south component and is related to upwelling and downwelling processes which can eventually cause the enhancement or reversal of the residual circulation, as mentioned in the introduction. The alongshore component $\left(\mathrm{Q}_{\mathrm{y}}\right)$ depends on winds with a predominant east-west component; these winds, when strong enough, can directly pull surface water into or out of the Ría and likewise alter the residual circulation pattern.

The mean integrated Brunt-Väisälä frequency $\left(\overline{\mathrm{N}}^{2}\right)$, an estimate of the stability of the water column (Millard et al., 1990), was calculated according to Doval et al. (1997).

$$
\overline{\mathrm{N}}^{2}=\frac{\mathrm{g}}{\mathrm{z}} \ln \left(\frac{\rho_{b}}{\rho_{s}}\right)
$$

where $\mathrm{g}$ is gravity, $\mathrm{z}$ is water depth, $\rho_{s}$ is surface density and $\rho_{b}$ is bottom density.

\section{Box model of residual circulation and phytoplankton}

\section{Residual circulation}

Fluxes were derived from the salinity and temperature profiles using an improved 2-dimensional kinematic non-steady state mass/heat weighed box model similar to the one developed and extensively described by Rosón et al. (1997) for a similar estuarine system. The calculations are based on the mass and energy conservation principle applied to 2 conservative properties, salinity and temperature, inside closed elements or boxes defined inside the Ría on the hypothesis that changes of these properties within such elements are exclusively due to exchanges across their boundaries, and assuming that the volume of the boxes is constant over a tidal cycle (Officer, 1980).

As Figure 1 shows, the Ría de Vigo was divided into 3 boxes limited by a series of walls that were perpendicular to its axis and contained sampling stations. On the basis of a 2-layered circulation pattern these boxes were segmented into 2 levels (upper and bottom) separated by a zero-velocity depth $\left(Z_{c}\right)$. The terms in the Volume-S-T budget for each box are presented in Figure 2. Rainfall data $(L)$ were obtained from the Meteorological Observatory at Vigo Airport ( $42^{\circ} 14^{\prime} \mathrm{N}, 8^{\circ} 18^{\prime} \mathrm{W}$ ) and corrected considering its altitude above sea level. Evaporation (E) was obtained with an empirical relationship depending on wind velocity and vapour pressure

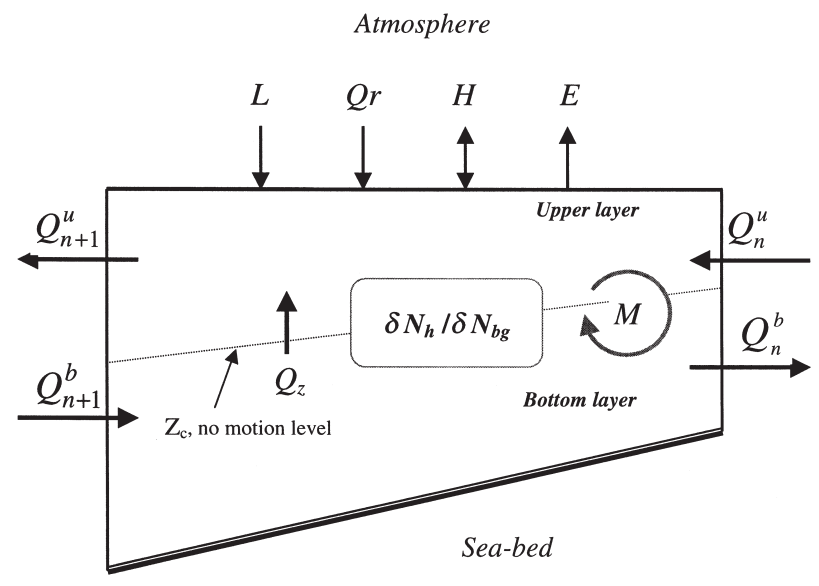

FIG. 2. - Notation for fluxes across boundaries of a generic box $\mathrm{n}$ segmented into two layers. $Q^{u}{ }_{n}, Q^{u}{ }_{n+1}$ are inward and outward convective flows to the upper layer; $Q^{b}{ }_{n+1}^{n+1}, Q^{b}$ are inward and outward horizontal convective flows to the bottom layer; $Q_{z}$ : upward convective flow from the bottom to the upper layer; $M$ : vertical turbulent diffusive flow (mixing between upper and bottom layer); $L$ : precipitation; $E$ : Evaporation; $Q r$ : continental runoff; $H$; heat exchange with the atmosphere; $Z_{c}$ : zero-velocity depth.

(Rosón et al., 1997). Continental flow $\left(Q_{r}\right)$ was calculated according to Ríos et al. (1992) using rainfall in the drainage basin. Heat exchange $(H)$ was solved as a sum of terms (irradiation, atmospheric and oceanic back radiation, conduction and reflection) whose evaluation is thoroughly explained in Rosón et al. (1997). For salinity and temperature mean values, vertical CTD profiles were used and averaged using the geometric characteristics of each box.

For the sake of brevity no thorough report of the mathematical model will be made in this paper and instead we will emphasise the application of the box model to the study of phytoplankton. A more detailed description of the calculation of residual fluxes can be found in Rosón et al. (1997) and in Pardo et al. (2001).

\section{Phytoplankton dynamics}

Unlike conservative properties, when calculating budgets of phytoplankton we must take into account not only the fluxes crossing the boxes and transporting phytoplanktonic populations (hydrodynamic processes), but also the biogeochemical processes. As mentioned in the introduction, these biogeochemical processes account for the inputs and outputs that occur within the boxes (e.g. growth, respiration, mortality, grazing and sedimentation) and explain the non-conservative behaviour (Smith and Hollibaugh, 1997). Hence, we can express the net temporal change of the standing stock of a certain 
group of phytoplankton in a box as the sum of a hydrodynamic component, $\delta N_{h}$, and a biogeochemical one, $\delta N_{b g}$ :

$$
\frac{d N_{B}}{d t} V_{B}=\delta N_{h}+\delta N_{b g}
$$

where $V_{B}$ is the volume of the box, and $d N_{B} / d t$ is the total temporal change of phytoplankton abundance in a single box for a given day $t_{n}$, which can be expressed as an average increment between the previous sampling day, $t_{n-l}$, the present sampling day, $t_{n}$ and the following sampling day, $t_{n+1}$.

$$
\frac{d N_{B}}{d t}=\frac{1}{2} \cdot\left\{\frac{N_{B t_{n}}-N_{B t_{n-1}}}{t_{n}-t_{n-1}}+\frac{N_{B t_{n+1}}-N_{B t_{n}}}{t_{n+1}-t_{n}}\right\}
$$

Once we have obtained residual fluxes we can easily calculate the hydrodynamic component rate $\delta N_{h}$ as shown in (5):

$$
\delta N_{h}=\sum_{n} Q_{n} \cdot N_{Q}
$$

where $N_{Q}$ is the phytoplankton abundance carried by each flow $Q_{n}$.

Finally, after calculating the hydrodynamic component $\left(\delta N_{h}\right)$ by (5) and the net temporal change $d N_{B} / d t$ by (4), the rate of change due to biogeo- chemical processes $\left(\delta N_{b g}\right)$ can be simply derived by subtracting both.

$$
\delta N_{b g}=\frac{d N_{B}}{d t}-\delta N_{h}
$$

Since our intention is to give an insight into the overall selection processes that occur within the system, results to be presented in this paper will refer to the Ría as a whole. Moreover, so as to be able to compare the results obtained for different populations, we will relate both the hydrodynamic and biogeochemical rates found to the total group biomass. Thus, hereafter, $\delta N_{h}$ and $\delta N_{b g}$ values will express a daily change of biomass in relation to the total group biomass present in the Ría. A 0.5 value means that $50 \%$ of the biomass present in the Ría is gained (if positive) or lost (if negative) in one day by the processes mentioned above.

\section{RESULTS}

In order to analyse the box-model results it is necessary to consider the meteorological, hydrographic and biological contexts of the samplings, so, a brief draft of these contexts will be included. More

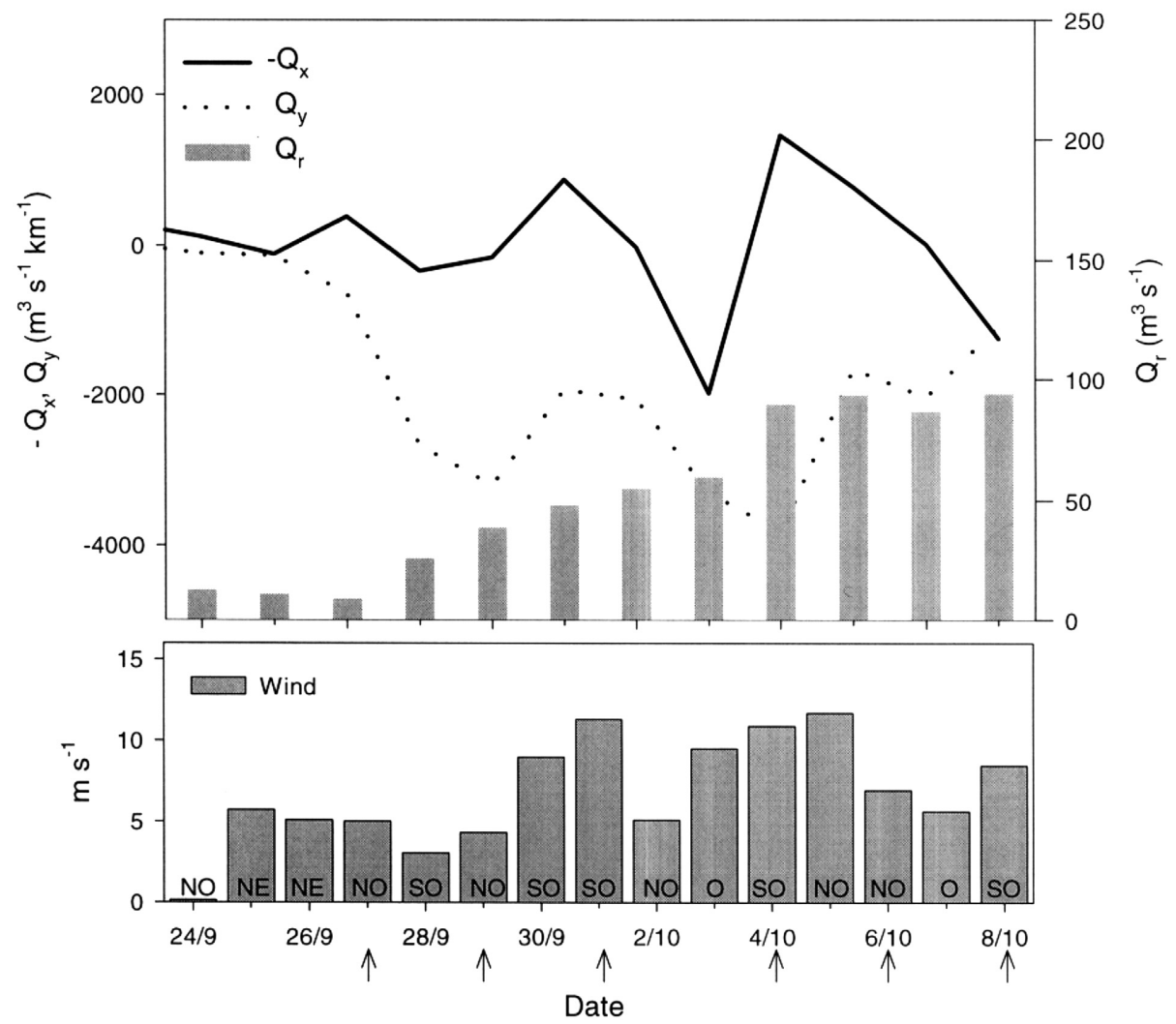

FIG. 3. - Ekman transport components, wind speed and direction calculated at $43^{\circ} \mathrm{N} 11^{\circ} \mathrm{W}$ and continental runoff in the Ría de Vigo. Downwelling period (September-October 1993). 
detailed descriptions are available in previous works (Fermín et al., 1996; Figueiras et al., 1996; Tilstone et al., 1999; Tilstone et al., 2000).

\section{September-October 1993}

\section{Meteorology, hydrography, nutrients and phytoplankton}

The Ekman transport components, wind speed and the continental runoff from 24 September to 8 October are shown in Figure 3. Decreasing negative values of $Q_{y}$ were minimal on 5 October $\left(-3800 \mathrm{~m}^{3}\right.$ $\mathrm{s}^{-1} \mathrm{~km}^{-1}$ ) and correspond to westerly winds blowing directly over the Ría. The associated alongshore transport first caused the slow-down of the positive residual circulation pattern and finally favoured its reversal and the introduction of relatively warmer, nutrient-depleted coastal water into the Ría. This was recorded in $\mathrm{T}, \mathrm{S}$ and $\mathrm{NO}_{3}{ }^{-}$values (Table 1) on 1 October. The Ría was less stratified and this was reflected by $\overline{\mathrm{N}}^{2}$ values that were extremely low on 1 October. $Q_{x}$ values were generally lower $\left(<2000 \mathrm{~m}^{3}\right.$ $\mathrm{s}^{-1} \mathrm{~km}^{-1}$ ) and acquired some relevance towards the end of the period, favouring the reestablishment of positive residual circulation after 4 October (we have represented $-Q_{x}$ so that positive values imply upwelling). This reestablishment was also supported by the simultaneous increase in continental runoff, which brought about the cooling, and above all the freshening up, of the upper inner box, along with an

TABLE 1. - Summary of Brunt-Väisälä $\left(\overline{\mathrm{N}}^{2}, \mathrm{~min}^{-2}\right)$, nitrate $\left(\mathrm{NO}_{3}^{-}, \mu \mathrm{mol} \mathrm{kg}{ }^{-1}\right)$, temperature $\left(\mathrm{T},{ }^{\circ} \mathrm{C}\right)$, salinity $(\mathrm{S})$, and phytoplankton abundance (cells $\mathrm{ml}^{-1}$ ) values in the Ría de Vigo (September-October 1993).

\begin{tabular}{|c|c|c|c|c|c|c|c|c|c|}
\hline \multirow[t]{2}{*}{ Day } & \multirow[t]{2}{*}{ Box } & \multirow[t]{2}{*}{$\overline{\mathrm{N}}^{2}$} & \multirow{2}{*}{$\mathrm{NO}_{3}^{-}$} & \multirow[t]{2}{*}{$\mathrm{T}$} & \multirow[t]{2}{*}{$S$} & \multicolumn{2}{|c|}{ Diatoms } & \multicolumn{2}{|c|}{ G. catenatum } \\
\hline & & & & & & per Box & whole Ria & per Box & whole Ria \\
\hline \multirow[t]{3}{*}{$29-9-93$} & 1 & 2.04 & 1.65 & 16.02 & 35.08 & 3462 & \multirow[t]{3}{*}{1694} & 4 & \multirow[t]{3}{*}{12} \\
\hline & 2 & 1.34 & 2.64 & 15.76 & 35.41 & 2548 & & 8 & \\
\hline & 3 & 1.25 & 4.41 & 15.22 & 35.56 & 1160 & & 15 & \\
\hline \multirow[t]{3}{*}{$1-10-93$} & 1 & 1.32 & 0.81 & 15.97 & 34.91 & 2078 & \multirow[t]{3}{*}{554} & 2 & \multirow[t]{3}{*}{66} \\
\hline & 2 & 0.91 & 0.82 & 15.99 & 35.24 & 722 & & 52 & \\
\hline & 3 & 0.97 & 0.90 & 15.91 & 35.35 & 331 & & 78 & \\
\hline \multirow[t]{3}{*}{$4-10-93$} & 1 & 3.52 & 2.06 & 15.86 & 33.94 & 19 & \multirow[t]{3}{*}{66} & 1 & \multirow[t]{3}{*}{228} \\
\hline & 2 & 1.05 & 2.21 & 15.78 & 34.99 & 52 & & 174 & \\
\hline & 3 & 0.85 & 2.58 & 15.60 & 35.28 & 77 & & 274 & \\
\hline \multirow[t]{3}{*}{$6-10-93$} & 1 & 7.79 & 2.30 & 15.83 & 33.07 & 18 & \multirow[t]{3}{*}{118} & 85 & \multirow[t]{3}{*}{72} \\
\hline & 2 & 3.26 & 2.62 & 15.66 & 34.48 & 44 & & 74 & \\
\hline & 3 & 1.00 & 5.12 & 14.93 & 35.07 & 159 & & 70 & \\
\hline
\end{tabular}

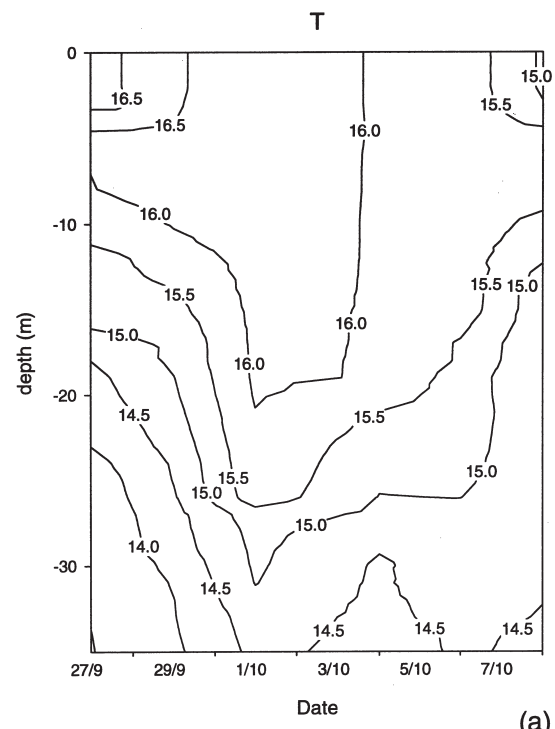

(a)

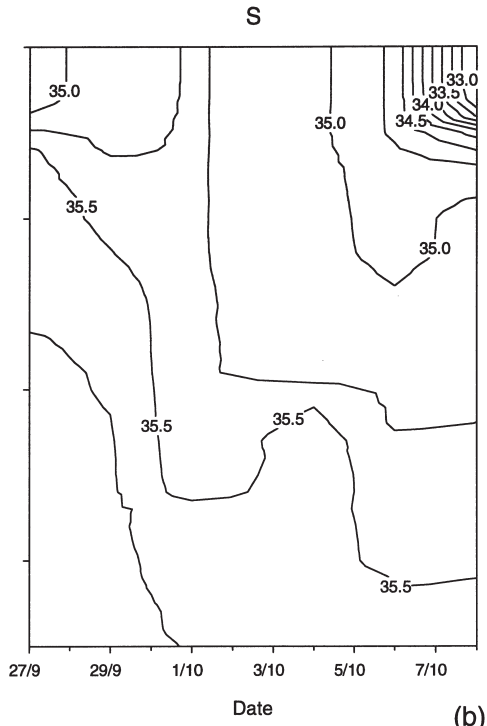

(b)

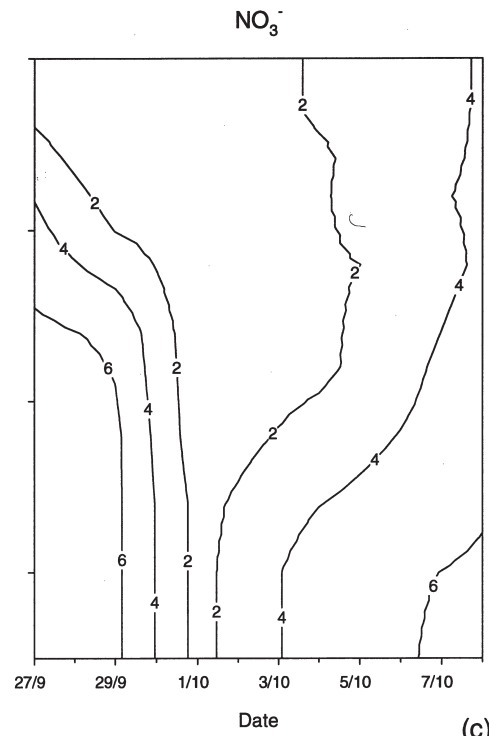

(c)

FIG. 4. - Time course of (a) temperature $\left(\mathrm{T},{ }^{\circ} \mathrm{C}\right)$, (b) salinity $(\mathrm{S})$ and (c) nitrate $\left(\mathrm{NO}_{3}^{-}, \mu \mathrm{mol} \mathrm{kg}{ }^{-1}\right)$ profiles at Stn. 3. Arrows indicate sampling dates. Downwelling period (September-Öctober 1993). 
increase in $\mathrm{NO}_{3}^{-}$levels. This in turn justifies the higher $\overline{\mathrm{N}}^{2}$ values in Box 1, which eventually affected the whole Ría. We can observe the same processes in the $\mathrm{T}, \mathrm{S}$ and $\mathrm{NO}_{3}{ }^{-}$profiles over time for a representative station (Fig. 4). The downwelling event is recorded as a downward displacement of the isopycnals and isotherms from 29 September to 1 October, along with a decrease in nitrate levels. The entrance of coastal water leaves a homogeneous water column, which recovers its stratification at the end of the period, mainly due to the arrival of fresh water.

The last two columns in Table 1 show the selection of Gymnodinium catenatum, whose population grew sharply (by a factor of 20 in 6 days) mainly in the outermost boxes reaching a maximum on October 4 . The cell abundance illustrates the dimension of the bloom: G. catenatum outnumbered the totality of the diatom community. Diatoms, on the contrary, were abundant on 29 September (mean value for the Ría $=1694$ cells $\mathrm{ml}^{-1}$, i.e. volume-averaged for the 3 boxes) but as the downwelling situation progressed, their abundance decreased by $95 \%$ (66 cells $\mathrm{ml}^{-1}$ on 4 October). The diatom population recovered on 6 October but only in the last box. By contrast the $G$. catenatum population followed a decreasing pattern on 6 October: its number descended and it became more homogeneously distributed.

\section{Box model results}

\section{Residual circulation}

A general description of the flows corresponding to a positive residual circulation pattern is depicted in Figure 2. The corresponding residual surfaceaveraged velocities were calculated simply by dividing those flows by correspondent boundary wall surfaces and are presented in Figure 5. Arrows follow the direction of the movement and negative values indicate reversal of the residual circulation, generally associated with downwelling.

The horizontal circulation on 29 September 1993 (mean $Q_{n}$ absolute value for the Ría $=2.0 \mathrm{~km} \mathrm{~d}^{-1}$, i.e. averaged for the upper and bottom walls at the 4 stations) showed the effect of westerly winds, which forced coastal water towards the Ría, blocking the positive estuarine circulation at its mouth. This can be seen in low and negative velocity values found for Box 3. In the inner Ría, however, a positive circulation pattern prevailed (bottom inward and upper
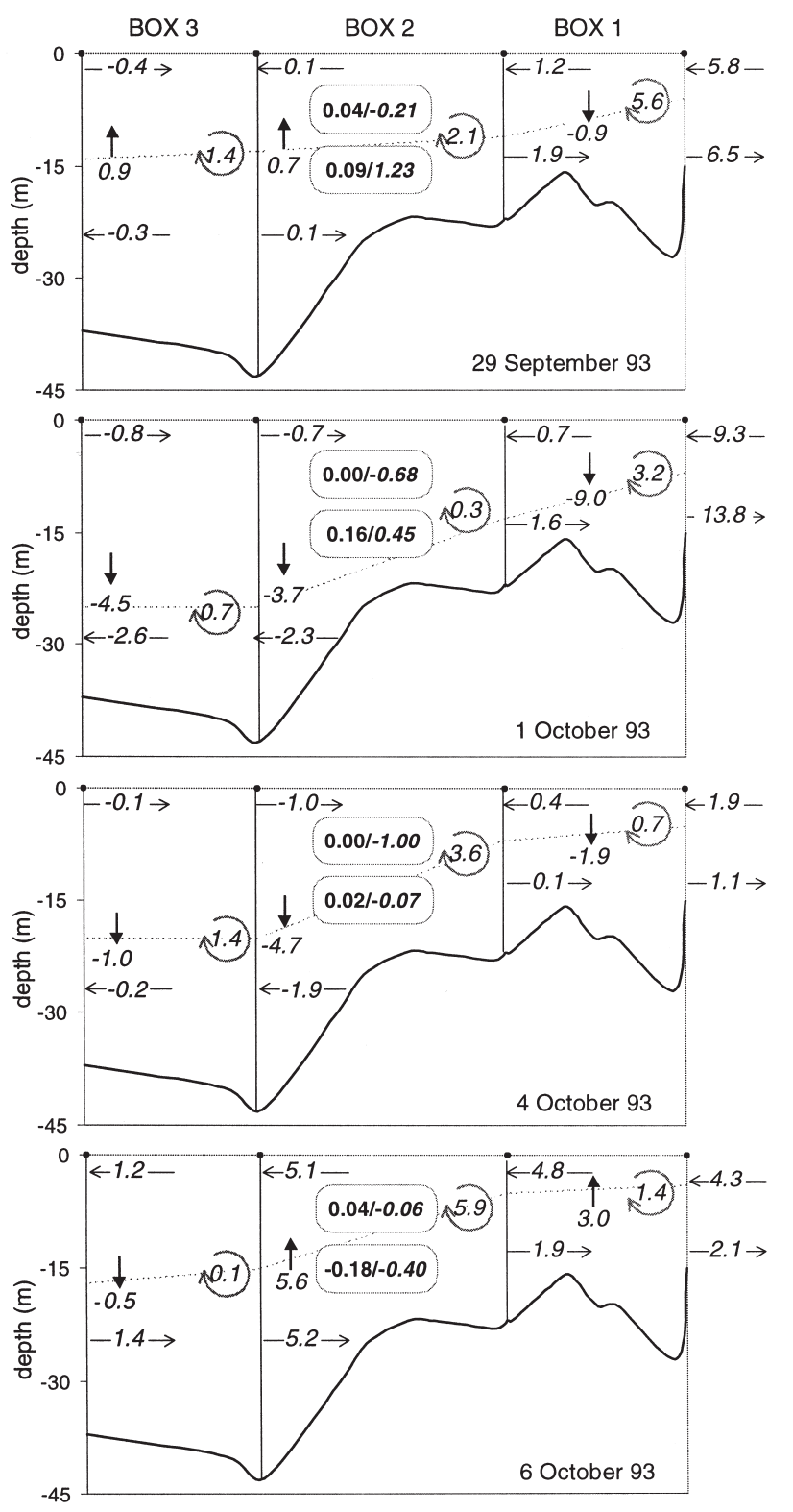

FIG. 5. - Horizontal $(\leftrightarrow)$ and vertical $(\diamond)$ residual fluxes expressed as velocities ( $\mathrm{km} \mathrm{d}^{-1}$ and $\mathrm{m} \mathrm{d}^{-1}$ respectively).( $\square$ ) Hydrodynamic $\delta N_{h}$ (left, bold) and biogeochemical $\delta N_{b p}$ (right, bold and italics) rate of change of diatoms (upper) and Gymnodinium catenatum (lower) abundance in $\mathrm{d}^{-1}$.

outward flows). Both the vertical convective $\left(Q_{z}\right)$ and mixing $(M)$ velocities were moderate when compared with those of the following days. As westerly winds intensified on 1 October, the enhanced transport of water caused a strong reversal of the estuarine circulation, as can be seen in the external box, and horizontal velocities increased (mean value of $4.0 \mathrm{~km} \mathrm{~d}^{-1}$ ). Strong negative vertical velocities (mean $Q_{z}$ value for the Ría $=-5.7 \mathrm{~m} \mathrm{~d}^{-1}$, i.e. averaged for the 3 boxes) indicated a net downward transport of water from upper to bottom layers. These nega- 
tive velocities were concurrent with a strong deepening of the zero-velocity depth, as would be expected for a downwelling situation. Residual velocities on 4 October indicated the slight moderation of the downwelling observed as a decrease in horizontal (mean absolute value $=0.8 \mathrm{~km} \mathrm{~d}^{-1}$ ) and vertical (mean value $=-2.5 \mathrm{~m} \mathrm{~d}^{-1}$ ) convective velocities. Coinciding with the higher runoff, stratification developed in the interior of the estuary (Box 1): the zero velocity level rose and mixing was inhibited (mean $M$ value for the Ría $=0.7 \mathrm{~m} \mathrm{~d}^{-1}$ ). The reestablishment of a positive circulation pattern took place on 6 October, as is reflected by almost all-positive velocities.

\section{Phytoplankton dynamics}

The change in biomass associated with both the hydrographic $\left(\delta N_{h}\right)$ and the biogeochemical component $\left(\delta N_{b g}\right)$ for both the diatom and the G. catenatum assemblages in the whole of the Ría is shown in Figure 5 (autumn period). Notice the differences between absolute values of both components, $\delta N_{h}$ always being lower than $\delta N_{b g}$. This highlights the importance of biogeochemical processes occurring within the Ría during this downwelling period. Physical dispersion processes associated with residual flows, on the contrary, did not have such a marked effect on the variation of phytoplanktonic communities. On 29 September $\delta N_{h}$ positive values evidenced a net entrance of diatoms and G. catenatum associated with water transport, which represented respectively $4 \%$ and $9 \%$ of their standing stock. Under downwelling conditions ( 1 and 4 October), $\delta N_{h}$ values kept relatively low and positive. On 6 October, there was a net hydrodynamic exportation of G. catenatum, as shown by the negative $\delta N_{h}$ value $(=-0.18)$.

The rate of change that is not dependent upon physical dispersion, $\delta N_{b g}$, showed much higher values. Diatom abundance decreased $21 \%$ due to biogeochemical processes on 29 September, whereas G. catenatum assemblage accumulated and its standing stock doubled. On 1 October, when the circulation was inverted, the differences persisted: the diatom abundance diminished sharply (68\% of the total cell abundance was lost) and the G. catenatum population increased by $45 \%$. Negative $\delta N_{b g}$ values were found for both communities on 4 October, although the loss was negligible in G. catenatum $(\delta$

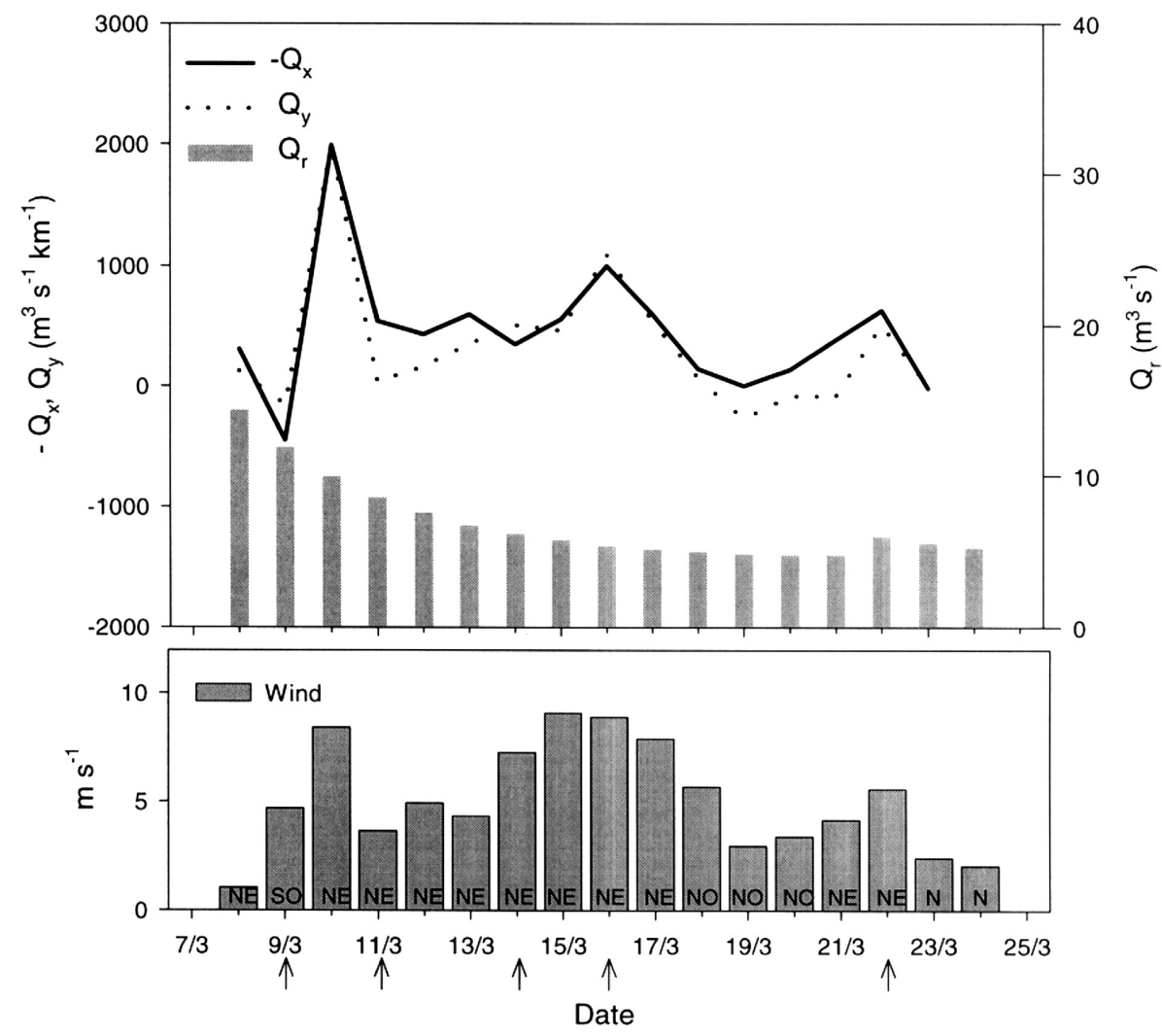

FIG. 6. - Ekman transport components, wind speed and direction calculated at $43^{\circ} \mathrm{N} 11^{\circ} \mathrm{W}$ and continental runoff in the Ría de Vigo. Arrows indicate sampling dates. Upwelling-relaxation period (March 1994). 
TABLE 2. - Summary of Brunt-Väisälä $\left(\overline{\mathrm{N}}^{2}, \mathrm{~min}^{-2}\right)$, nitrate $\left(\mathrm{NO}_{3}^{-}, \mu \mathrm{mol} \mathrm{kg}^{-1}\right)$, temperature $\left(\mathrm{T},{ }^{\circ} \mathrm{C}\right)$, salinity $(\mathrm{S})$, and phytoplankton abundance (cells $\mathrm{ml}^{-1}$ ) values in the Ría de Vigo (March 1994).

\begin{tabular}{|c|c|c|c|c|c|c|c|c|c|}
\hline Day & Box & $\overline{\mathbf{N}}^{2}$ & $\mathrm{NO}_{3}^{-}$ & $\mathrm{T}$ & $\mathrm{S}$ & \multicolumn{2}{|c|}{$\begin{array}{l}\text { Thalassiosira spp. } \\
\text { per Box whole Ria }\end{array}$} & \multicolumn{2}{|c|}{$\begin{array}{l}\text { Chaetoceros spp. } \\
\text { per Box whole Ria }\end{array}$} \\
\hline $11-3-94$ & $\begin{array}{l}1 \\
2 \\
3\end{array}$ & $\begin{array}{l}6.93 \\
2.31 \\
1.39\end{array}$ & $\begin{array}{l}4.44 \\
4.33 \\
4.86\end{array}$ & $\begin{array}{l}13.21 \\
13.04 \\
12.92\end{array}$ & $\begin{array}{l}34.37 \\
34.99 \\
35.25\end{array}$ & $\begin{array}{l}134 \\
190 \\
191\end{array}$ & 187 & $\begin{array}{r}470 \\
197 \\
89\end{array}$ & 144 \\
\hline $14-3-94$ & $\begin{array}{l}1 \\
2 \\
3\end{array}$ & $\begin{array}{l}4.59 \\
1.33 \\
0.98\end{array}$ & $\begin{array}{l}8.66 \\
6.95 \\
5.41\end{array}$ & $\begin{array}{l}12.78 \\
12.78 \\
12.77\end{array}$ & $\begin{array}{l}34.95 \\
35.42 \\
35.50\end{array}$ & $\begin{array}{r}85 \\
172 \\
244\end{array}$ & 214 & $\begin{array}{l}428 \\
361 \\
333\end{array}$ & 347 \\
\hline $16-3-94$ & $\begin{array}{l}1 \\
2 \\
3\end{array}$ & $\begin{array}{l}1.70 \\
0.71 \\
0.44\end{array}$ & $\begin{array}{l}8.07 \\
6.99 \\
6.98\end{array}$ & $\begin{array}{l}12.90 \\
12.86 \\
12.74\end{array}$ & $\begin{array}{l}35.03 \\
35.41 \\
35.57\end{array}$ & $\begin{array}{r}50 \\
114 \\
56\end{array}$ & 72 & $\begin{array}{l}476 \\
437 \\
230\end{array}$ & 303 \\
\hline 22-3-94 & $\begin{array}{l}1 \\
2 \\
3\end{array}$ & $\begin{array}{l}2.25 \\
1.00 \\
0.79\end{array}$ & $\begin{array}{l}3.80 \\
3.99 \\
5.07\end{array}$ & $\begin{array}{l}13.06 \\
12.95 \\
12.79\end{array}$ & $\begin{array}{l}34.95 \\
35.18 \\
35.48\end{array}$ & $\begin{array}{l}31 \\
74 \\
64\end{array}$ & 65 & $\begin{array}{r}896 \\
1304 \\
1090\end{array}$ & 1136 \\
\hline
\end{tabular}

$\left.N_{b g}=-0.07\right)$ as compared to the diatom community $\left(\delta N_{b g}=-1.00\right)$. On 6 October loss processes could still be detected as negative $\delta N_{b g}$ values for both groups involved in the study.

\section{March 1994}

\section{Meteorology, hydrography, nutrients and phytoplankton}

The Ekman transport components (Fig. 6) on days previous to the sampling showed the influence of decreasing northeasterly winds, which eventually changed to south-west and caused the relaxation of a previous upwelling period. After 9 March the winds turned back to the north-east, which caused upwelling. This was detected in the Ría from 11 to 16 March and can be seen in the increase in salinity and $\mathrm{NO}_{3}^{-}$levels in the 3 boxes, whereas temperature values decreased (Table 2). Notice the uplifting of the T, $\mathrm{S}$ and $\mathrm{NO}_{3}^{-}$isolines for the same period (Fig. 7). From 18 March on, the influence of westerly winds was recorded as a reduction in $\mathrm{Q}_{\mathrm{x}}$ and $\mathrm{Q}_{\mathrm{y}}$ values, which again produced the relaxation of the upwelling towards the end of the period. This can be seen in the decreasing $\mathrm{NO}_{3}^{-}$levels on 22 March, while salinity and temperature varied slightly. Continental runoff showed very low values (decreasing from 14 to $5 \mathrm{~m}^{3}$ $\mathrm{s}^{-1}$ ) and had little influence on the circulation pattern.
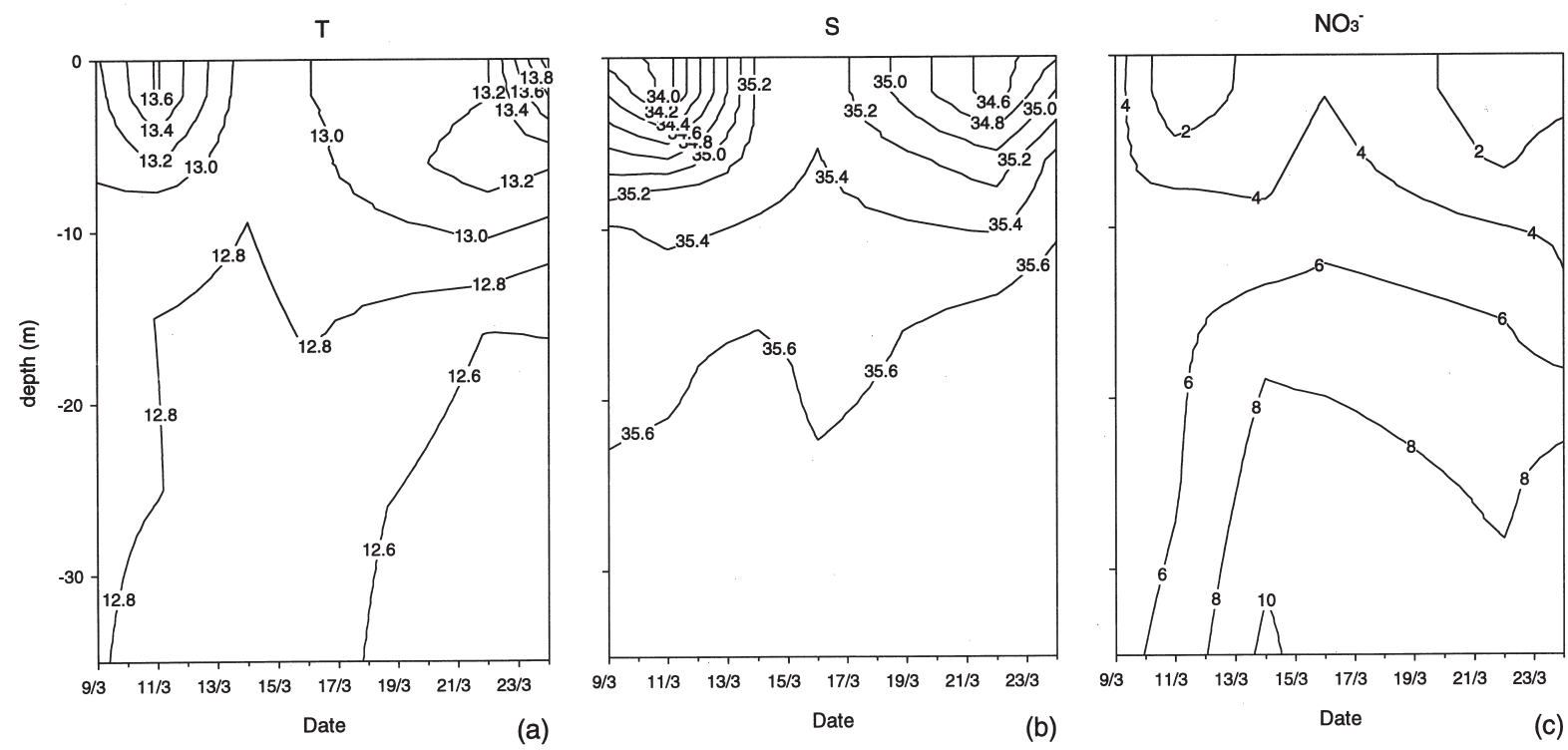

FIG. 7. - Time course of (a) temperature $\left(\mathrm{T},{ }^{\circ} \mathrm{C}\right)$, (b) salinity $(\mathrm{S})$ and (c) nitrate $\left(\mathrm{NO}_{3}^{-}, \mu \mathrm{mol} \mathrm{kg}^{-1}\right)$ profiles at Stn. 3. Upwelling-relaxation period (March 1994). 
The stratification increased at the end of the sampling period, as we can see in the salinity and temperature profiles at Station 3 (Fig. 7).

The phytoplankton abundance values presented in Table 2 show a succession event between two genera of diatoms. On 11 March Thalassiosira spp. was more abundant than Chaetoceros spp. (values for the whole Ría), especially in Box 3. However, from 14 March Thalassiosira spp. standing stock followed a decreasing trend, whereas Chaetoceros spp. abundance increased by a factor of 3 during the same sampling period (from 347 to 1136 cells $\mathrm{ml}^{-1}$ ).

\section{Box model results}

\section{Residual circulation}

Unlike the autumn situation, a positive circulation pattern was present through the whole March sampling period (Fig. 8). The relatively low horizontal and vertical fluxes on 11 March 1994 (mean velocity, $3.2 \mathrm{~km} \mathrm{~d}^{-1}$ and $2.6 \mathrm{~m} \mathrm{~d}^{-1}$ respectively) might be regarded as a consequence of the lack of continuity of the winds blowing on the previous days. The highest horizontal residual velocities in the Ría were observed on 14 March (mean velocity, $6.0 \mathrm{~km} \mathrm{~d}^{-1}$ ), indicating upwelling. The uplifting of deep water brought about the intensification of the circulation, which was also apparent in the enhanced vertical upward transport (maximum velocity, $14.0 \mathrm{~m} \mathrm{~d}^{-1}$ in Box 3) and mixing (up to $7.1 \mathrm{~m} \mathrm{~d}^{-1}$ in Box 2). Values on 16 March were typical of an upwelling scenario too, but slightly lower. The circulation was slower than on the previous day and only mixing increased, especially in the inner box (mean value $11.1 \mathrm{~m} \mathrm{~d}^{-1}$ ), a process presumably facilitated by the already eroded stratification. The horizontal velocities found on 22 March were substantially lower (mean velocity for the Ría, $1.2 \mathrm{~km} \mathrm{~d}^{-1}$ ) and corresponded to an upwelling relaxation event $\left(\mathrm{Q}_{\mathrm{x}}\right.$ and $\mathrm{Q}_{\mathrm{y}}$ values close to zero). As the pumping ceased, mixing and vertical transport diminished (mean values, 1.8 and $0.9 \mathrm{~m} \mathrm{~d}^{-1}$ respectively).

\section{Phytoplankton dynamics}

On 11 March $\delta N_{h}$ negative values expressed the initial exportation of Thalassiosira spp. and Chaetoceros spp. communities, which means that $10 \%$ and $15 \%$ of the respective biomass was lost through advection. The loss was particularly strong on 14 March (79\% for Thalassiosira spp. and 56\% for

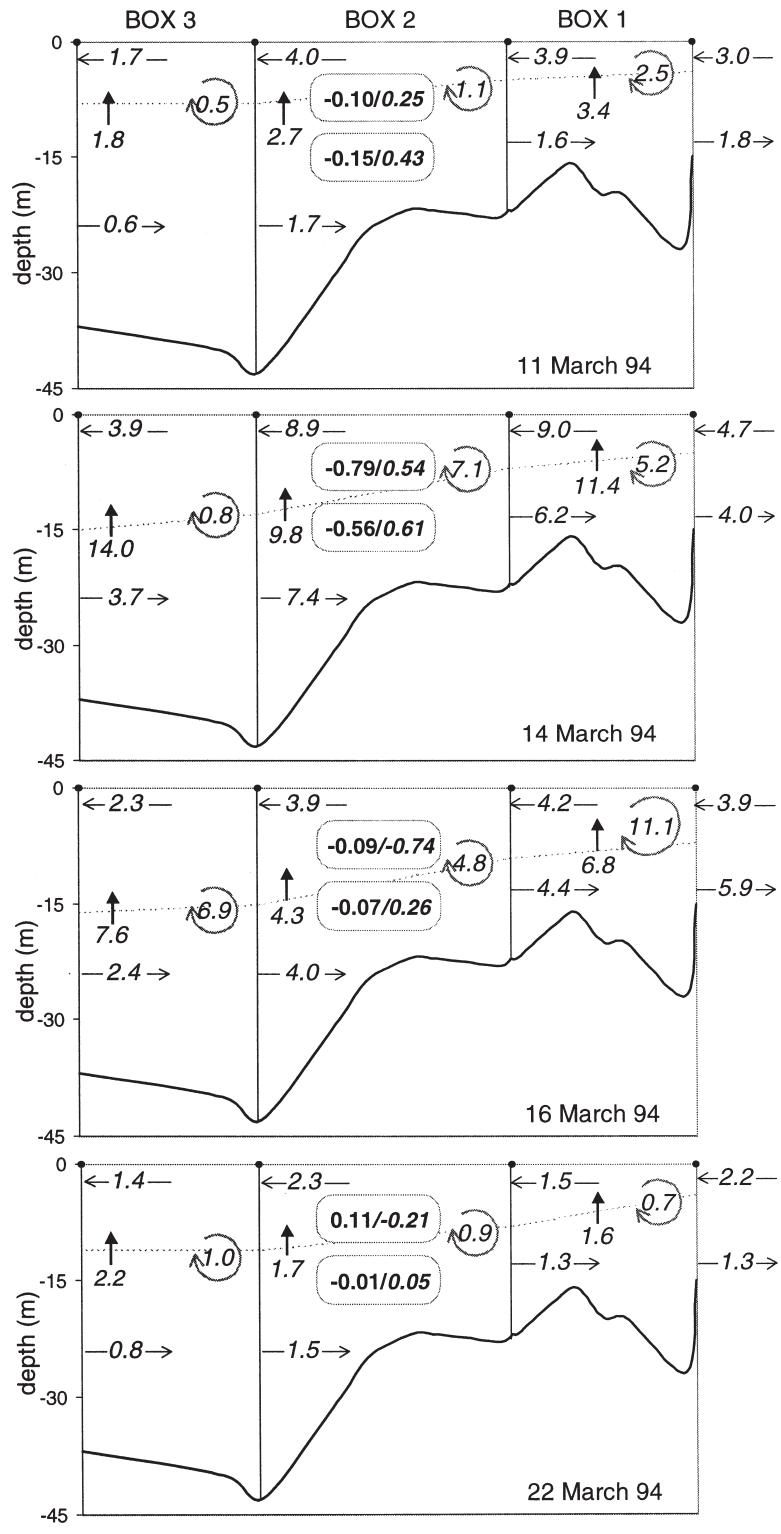

FIG. 8. - Horizontal $(\leftrightarrow)$ and vertical $(\diamond)$ residual fluxes expressed as velocities $\left(\mathrm{km} \mathrm{d}^{-1}\right.$ and $\mathrm{m} \mathrm{d}^{-1}$ respectively).( $\square$ ) Hydrodynamic $\delta N_{h}$ (left, bold) and biogeochemical $\delta N_{h p}$ (right, bold and italics) rate of change of Thalassiosira spp.(upper) and Chaetoceros spp.(lower) abundance in $\mathrm{d}^{-1}$.

Chaetoceros spp.), when the upwelling was more intense. As the upwelling weakened on 16 March, a balance between hydrodynamic losses and gains was established (as indicated by low $\delta N_{h}$ values). Finally, on March 22 there was an input of Thalassiosira spp. biomass (representing $11 \%$ of the total biomass present in the Ría) while almost no change was recorded for Chaetoceros spp.

The effect of biogeochemical processes on the two diatom assemblages is expressed by $\delta N_{b g}$ values. Beginning on 11 March and especially on 14 
March, our results show the accumulation of Thalassiosira spp. and Chaetoceros spp. biomass in the Ría. On 14 March Thalassiosira spp. standing stock increased by $54 \%$ regardless of physical dispersion processes, whereas that of Chaetoceros spp. increased by $61 \%$. The greatest differences arose in the second part of the sampling period. Thus, while Chaetoceros spp. accumulation continued, the biogeochemical rate of change for Thalassiosira spp. (negative on 16 and 22 March) indicated a strong loss process.

\section{DISCUSSION}

Separating the effects of hydrodynamic and biogeochemical processes on phytoplankton assemblages becomes a difficult issue in upwelling zones due to the tight coupling between these two processes. In general, hydrographic data and phytoplankton species distributions can merely provide a static description, which is then used to infer the effect of hydrodynamic processes on the evolution of the phytoplankton populations. Box models can supply more quantitative information so that a more dynamic view can be achieved. In this paper we used an improved 2-D kinematic box model conceived to describe the residual circulation and calculate flows of phytoplankton. The box model results allowed us to estimate the relative influence of the hydrodynamic factors (related to movements of water) and biogeochemical factors (comprising all other processes such as growth, mortality, passive sedimentation and grazing) on the succession events which characterised the sampling periods.

\section{September-October 1993}

Residual fluxes at the beginning of the autumn period (29 September) showed the blockage of the circulation caused by south-western winds. Such hydrodynamic conditions hardly brought about any variation in diatom and $G$. catenatum abundance linked to water transport ( $\delta N_{h}$ close to zero). Nonetheless, the hydrodynamic context might help to explain the differences between the biogeochemical rates of change found for the two phytoplankton groups. The relatively stagnant conditions did not favour the permanence of the initially abundant diatom community, which, due to its higher aggregation and sedimentation rates (Smetacek, 1985; Passow, 1991), sank in the water column towards levels of low irradiance and eventually died. Conversely, the growth of another red tide species such as $G$. catenatum is facilitated by low turbulence and stratification (Figueiras and Ríos, 1993; Fermín et $a l ., 1996)$ and might explain the high positive $\delta N_{b g}$ value. The intensification of the downwelling on 1 October brought about the reversal of the circulation, and a downward displacement of water associated with a homogenisation and a nutrient depletion (Tilstone et al., 1999) of the water column, which again hindered the development of the diatoms. $G$. catenatum, conversely, has shown itself capable of counteracting these displacements due to its ability to migrate vertically (Fraga et al., 1989; Figueiras et $a l ., 1994)$, which is favoured by the weakness of the physical gradient (Fermín et al., 1996). In addition, the hydrodynamic variation rate is also positive, which supports the accumulation of these dinoflagellates in the Ría and their selection. On 4 October, downwelling conditions persisted and the biogeochemical rate of change accounted for the disappearance (due to mortality and grazing) of the diatom community, which occupied a poorly irradiated and nutrient depleted medium (Tilstone et al., 1999). Red-tide events appear associated with coastal downwelling and have been related to open ocean blooms which were later introduced to the Ría by the reversal of circulation (Fraga et al., 1988; Fraga et al., 1989; Tilstone et al., 1994). Other authors, however, have pointed out that dinoflagellates were able to develop inside the Ría (Figueiras and Pazos, 1991; Figueiras et al., 1994; Fermín et $a l ., 1996)$ though they have a lower growth rate than diatoms (Banse, 1982). Up to now the matter remained unsolved due to the difficulties involved in estimating growth rates in the field and assessing the effect of the circulation pattern. On that score our results showed that the development of the red-tide forming dinoflagellate, G. catenatum was not exclusively a consequence of water inward transport, but mainly of the in situ growth of the standing stock inside the Ría (positive $\delta N_{b g}$ values on 29 September and 1 October). Red tide species are commonly assumed to be relatively slow growing. However, Smayda (1997) suggests that some dinoflagellates are capable of rapid growth and have growth rates for the genera Gymnodinium which are compatible with the $\delta N_{b g}$ values we found. On 6 October, the reestablishment of the positive estuarine circulation and the supply of nutrients propitiated the relatively higher accumulation of diatoms while G. catenatum was displaced out of the Ría. Horizontal and vertical 
velocities were similar to those found in previous works for periods with similar hydrographic conditions (Rosón et al., 1997; Villarino et al. 1995).

\section{March 1994}

Environmental conditions were clearly different during the March sampling period, with the predominance of an upwelling event, which intensified on 14 March and then relaxed. Upwelling lifted colder and richer waters towards the Ría. This led to the enhancement of positive residual circulation and the exportation of biomass, as can be inferred from negative values of $\delta N_{h}$. It also involved availability of nutrients, and enough turbulence to maintain phytoplankton populations in the upper layer. These suitable conditions for growth help to explain the high accumulation rates $\delta N_{b g}$ found for both genera. Horizontal and vertical fluxes were reduced on March 16 and 22, indicating relaxation of upwelling simultaneously to the shift between Chaetoceros spp. and Thalassiosira spp. The new, less energetic, hydrodynamic conditions involved a reduction in the rate of biomass lost through exportation and, above all, turned out to be much less favourable for the development of Thalassiosira spp. On the other hand, Chaetoceros spp. kept accumulating through biogeochemical processes, yet at a lower rate. Although the two genera coexist in upwelling systems (Hood et al., 1991; López-Jamar et al., 1992), in this case they show very different responses, probably due to their different morphological features (Margalef, 1978). Centric diatoms such as Thalassiosira spp. form large chains by cytoplasmatic extensions which favour their aggregation and sedimentation (Riebsell, 1989; Passow, 1991; Alldredge et al. 1995), probably also aided by the high cellular abundance during the first sampling days. By contrast, the long aerolated setae characteristic of Chaetoceros spp. can facilitate its flotation by causing a spiral rotation of the diatom chain (Goldsmith, 1966), allowing them to remain in the photic zone. Former work in the area has shown that Chaetoceros spp. are selected during upwelling-downwelling relaxation events coinciding with high primary production values in the Ría (Tilstone et al. 1999).

It is worth noting that although the selection of G. catenatum and Chaetoceros spp. appeared to happen mainly through biogeochemical processes, these processes can only be fully understood if we take into account the hydrodynamic phenomena that are related to downwelling and upwelling-relax- ation. Using the box model to differentiate between hydrodynamic and biogeochemical factors leads us once again to stress the tight relationship between the two.

\section{ACKNOWLEDGEMENTS}

This work was supported by the Xunta de Galicia (project Xuga 40205 B 92) and by the Comisión Interministerial de Ciencia y Tecnología (CICYT, project AMB92-0165). B. M. Míguez was financed by an FPU studentship from the Spanish Ministry of Education and Culture. We are grateful to the members of the Oceanography team at the Instituto de Investigacións Mariñas, Vigo, who participated in the sampling and analysis of nutrients and hydrographic parameters. We would like to thank an anonymous referee whose suggestions greatly improved the paper. Finally, we are indebted to X.A.G. Morán for his Sunday comments on the manuscript.

\section{REFERENCES}

Alldredge A.L., C. Gotschalk, U. Passow and U. Riebsell. - 1995. Mass aggregation of diatom blooms: Insights from a mesocosm study. Deep-Sea Res., 42: 9-27.

Álvarez-Salgado, X. A., G. Rosón, F.F. Pérez, F.G. Figueiras and Y. Pazos. - 1996. Nitrogen cycling in an estuarine upwelling system, the Ría de Arousa (NW Spain). I. Short-time-scale patterns of hydrodynamic and biogeochemical circulation. Mar. Ecol. Prog. Ser., 135: 259-273.

Banse, K. - 1982. Cell volume, maximal growth rates of unicellular algae and ciliates, and the role of ciliates in the marine pelagial. Limnol. Oceanogr., 27: 1059-1071.

Beer, T. - 1983. Environmental oceanography. Pergamon Press, Oxford.

Chase, J. - 1975. Wind-driven circulation in a Spanish estuary. Estuarine Coastal Mar. Sci., 3: 303-310.

Doval, M.D., X.A. Álvarez-Salgado and F.F. Pérez. - 1997. Dissolved organic matter in a temperate embayment affected by coastal upwelling. Mar. Ecol. Prog. Ser., 157: 21-37.

Dyer, K.R. - 1973. Estuaries, a physical introduction. John Wiley and sons, New York.

Fermín, E.G., F.G. Figueiras, B. Arbones and M.L. Villarino. 1996. Short-time scale development of a Gymnodinium catenatum population in the Ría de Vigo (NW Spain). J. Phycol., 32: 212-221.

Figueiras, F. G. and Y. Pazos. - 1991. Hydrography and Phytoplankton of the Ría de Vigo before and during a red tide of Gymnodinium catenatum Graham. J. Plankton Res. 3: 589-608.

Figueiras, F.G. and A.F. Ríos. - 1993. Phytoplankton Succession, red Tides and the hydrographic regime in the Rías Bajas of Galicia. In: T.J Smayda and Y. Shymizu (eds.), Toxic Phytoplankton Blooms in the Sea. pp. 239-244. Elsevier, New York.

Figueiras, F.G., K.J Jones, A.M Mosquera, X.A. Álvarez-Salgado, A. Edwards and M. MacDougall. - 1994. Red tide assemblage formation in an estuarine upwelling ecosystem: Ría de Vigo. $J$. Plank. Res., 16: 857-878.

Figueiras, F.G., E.F. Gómez, E. Nogueira and M.L Villarino. 1996. Selection of Gymnodinium catenatum under downwelling conditions in the Ria de Vigo. In: T. Yasumoto, Y. Oshima and Y. Fukuyo (eds), Harmful and Toxic Algal Blooms. 
pp. 215-218. Intergovernmental Oceanographic Commission of UNESCO.

Fraga, S., D.M Anderson, I. Bravo, B. Reguera, K.A. Steidinger and C.M. Yentsch. - 1988. Influence of upwelling relaxation on Dinoflagellates and Shellfish toxicity in Ría de Vigo, Spain. Estuar. Coast. Shelf Sci., 27: 349-361.

Fraga, S., S.M Gallaguer and D.M. Anderson. - 1989. Chain-forming dinoflagellates: an adaptation to a red tide. In: T. Okaichi, D.M Anderson and T. Nemoto (eds.), Red tides: Biology, Environmental Science and Toxicology. Elsevier, New York.

Goldsmith, H.L. - 1966. Red cells and Rouleaux in shear flow. Science 153: 1406-1407.

Hidy, G.M. - 1972. A review of recent air-sea interaction research. Bull. Am. Meteorol. Soc., 53: 1083-102.

Hood, R. R., M.R. Abbott, and A. Huyer. - 1991. Phytoplankton and photosynthetic light response in the coastal transition zone off northern California in June 1987. J. Geophys. Res. (C. Oceans), 96(C8): 14769-14780.

López-Jamar, E., R.M. Cal, G. González, R.B. Hanson, J. Rey, G. Santiago and K.R. Tenore. - 1992. Upwelling and outwelling effects on the benthic regime of the continental shelf off Galicia, NW Spain. J. Mar. Res., 50:465-488.

Margalef, R. - 1958. Temporal succession and spatial heterogeneity in phytoplankton. In: A.A Buzzati-Traverso (eds.), Perspectives in Marine Biology, pp. 323-348. Univ. California Press, Bereley \& Los Angeles.

Margalef, R. - 1978. Life forms of phytoplankton as survival alternatives in an unstable environment. Oceanol. Acta 1: 493-509.

Margalef, R., M. Durán and F. Sáiz. - 1955. El fitoplancton de la Ría de Vigo de Enero de 1953 a Marzo de 1954. Inv. Pesq., 2: 85-129.

Millard, R.C., W.B. Owens and N.P. Fotonoff. - 1990. On the calculation of the Brunt-Väisälä frequency. Deep-Sea Res., 31: 167-181.

Mouriño, C. and Fraga, F. - 1985. Determinación de nitratos en agua de mar. Inv. Pesq., 49: 81-6.

Nogueira E., F.F Pérez and A.F. Ríos. - 1997. Seasonal patterns and long term trends in an estuarine upwelling ecosystem (Ría de Vigo, NW Spain). Est. Coastal Shelf Sci., 44: 285-300

Officer, C.B. - 1980. Box models revisited. In: P. Hamilton and K.B Macdonalds (eds.), Estuarine and Wetland Processes with Emphasis on Modelling., 65-114. Plenum, New York.

Painchaud, J., D. Lefaivre, J.C. Therriault, and L. Legendre. - 1996. Bacterial dynamics in the upper St. Lawrence estuary. Limnol. Oceanogr., 41(8): 1610-1618.

Pardo, P.C., M. Gilcoto, F.F. Pérez. - 2001. Short time scale coupling between thermohaline and meteorology variabilities in the Ría de Pontevedra. Sci. Mar. 65(Suppl. 1): 229-240.

Passow, U. - 1991. Species-specific sedimentation and sinking velocities of diatoms. Mar. Biol., 108: 449-455.

Prego, R. - 1992. Flows and budgets of nutrient salts and organic carbon in relation to a red tide in the Ría of Vigo (NW Spain). Mar. Ecol. Prog. Ser., 79: 289-302.

Prego, R. - 1993. General aspects of carbon biogeochemistry in the Ría de Vigo, northwestern Spain. Geochem. Cosmochim. Acta., 57: 2041-2052.

Prego, R. and F. Fraga. - 1992. A simple model to calculate the residual flows in a Spanish Ría. Hydrographic consequences in the Ría of Vigo. Est. Coast. Shelf Sci., 34: 603-615.

Prego, R., F. Fraga and A.F. Ríos. - 1990. Water interchange between the Ría of Vigo and the coastal shelf. Sci. Mar. (Supl. 1), 54: 95-100.

Riebsell, U. - 1989. Comparisons of sinking and sedimentation rate measurements in a diatom winter/spring bloom. Mar. Ecol. Prog. Ser., 54:109-119.

Ríos, A.F., F. Nombela, G. Rosón and F. Fraga. - 1992. Calculation of runoff to an estuary. Ría de Vigo. Sci. Mar., 56:29-33.

Rosón, G., X.A. Álvarez-Salgado and F.F. Pérez. - 1997. A Nonstationary Box model to determine Residual Fluxes in a Partially Mixed Estuary, Based on Both Thermohaline Properties: Application to the Ría de Arousa (NW Spain). Estuar. Coast. Shelf Sci., 44: 249-262.

Rosón, G., X.A. Álvarez-Salgado and F.F. Pérez. - 1999. Carbon cycling in a large coastal embayment affected by wind-driven upwelling: short-time scale variability and spatial differences. Mar. Ecol. Prog. Ser., 176: 215-230.

Simpson, J.H. and T. P. Rippeth. - 1998. Non-conservative Nutrient Fluxes from Budgets for the Irish Sea. Estuar. Coast. Shelf Sci., 47: 707-714.

Smayda, T.J. - 1997. Harmful algal blooms: Their ecophysiology and general relevance to phytoplankton blooms in the sea. Limnol. Oceanogr., 42(5, part 2): 1137-1153.

Smetacek, V.S. - 1985. Role of sinking in diatom life-history cycles: ecological, evolutionary and geological significance. Mar. Biol., 84: 239-251.

Smith, S.V. and J.T Hollibaugh. - 1997. Annual cycle and interannual variability of ecosystem metabolism in a temperate climate embayment. Ecol. Monographs, 67(4): 509-533.

Souto, C., L. Fariña-Busto, E. Álvarez and I. Rodríguez. - 2001. Wind and tide current prediction using a 3-D finite difference model in the Ría de Vigo (NW Spain). Sci. Mar. 65(Suppl. 1): 269-276.

Tilstone, G.H., F.G. Figueiras, and F. Fraga. - 1994. Upwellingdownwelling sequences in the Generation of Red Tides in a Coastal System. Mar. Ecol. Prog. Ser., 112: 241-253.

Tilstone, G.H., F.G. Figueiras, E.G. Fermín and B. Arbones. 1999. Significance of nanophytoplankton photosynthesis and primary production in a coastal upwelling system (Ría de Vigo, NW Spain). Mar. Ecol. Prog. Ser., 183:13-27.

Tilstone, G.H., B.M. Míguez, F.G. Figueiras and E.G. Fermín. - (in press) Diatom dynamics in a coastal ecosystem affected by upwelling: coupling between species succession, circulation and biogeochemical processes. Mar. Ecol. Prog. Ser., 205: 23-41

Torres López, S., R.A Varela and E. Delhez. - 2001. Residual Circulation and Thermohaline Distribution of the Ría de Vigo: A 3-D Hydrodynamical Model. Sci. Mar., 65(Suppl. 1): 277-289.

Villarino, M.L., F.G. Figueiras, K.J. Jones, X.A. Alvarez-Salgado, J. Richard and A. Edwards. - 1995. Evidence of in situ diel vertical migration of a red-tide microplankton species in Ría de Vigo (NW Spain). Mar. Biol., 123: 697-617.

Wooster, W.S. A. Bakun and D.R. Mclain. - 1976. The seasonal upwelling cycle along the eastern boundary of the North Atlantic. J. Mar. Res., 334: 131-141. 